\title{
Treatment of Male Hypogonadism
}

\author{
a report by \\ Vijay Shivaswamy, MD and A Wayne Meikle, MD, FACP, FACE \\ Division of Endocrinology, University of Utah School of Medicine
}

\section{Physiology}

Androgens are responsible for the development and maintenance of secondary sexual characteristics, fertility, and anabolic effects of somatic tissues (lean body mass) in men.1,2 The primary androgen in circulation is testosterone. Production and secretion of testosterone is under the tonic control of leutinizing hormone (LH). LH and follicle-stimulating hormone (FSH) are secreted by the anterior pituitary and regulated by the pulsatile action of gonadotropin-releasing hormone $(\mathrm{GnRH})$ secreted by the hypothalamus. FSH, with the effects of testosterone, is responsible for spermatogenesis. Testosterone secretion is episodic and follows a distinct diurnal rhythm, ${ }^{1,2}$ with testosterone levels maximal in the morning and minimal in the evening.

\section{Hypogonadism}

Hypogonadism refers to deficiency of testosterone and spermatogenesis. Primary testicular failure is referred to as hypergonadotropic hypogonadism, where the testosterone levels are low and gonadotropins are appropriately elevated. Secondary or tertiary (hypogonadotropic) hypogonadism results from reduced secretion of gonadotropins ( $G n R H$ deficiency), and the LH and FSH levels are inappropriately low or normal with low testosterone levels. Differential diagnoses for hypogonadism are listed (see Tables 1 and 2). The clinical characteristics of testosterone deficiency are summarized in Table 3.,4

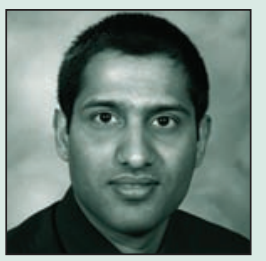

Vijay Shivaswamy, MD, is Assistant Professor in the Division of Endocrinology at the University of Utah School of Medicine. He is a board-certified endocrinologist and has a special interest in managing patients with pituitary disorders and osteoporosis. He also has expertise in reading dual $\mathrm{X}$-ray absorptiometry scans.

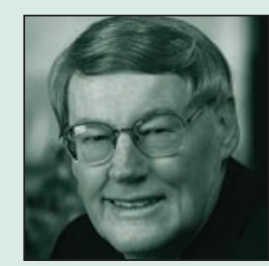

A Wayne Meikle, MD, FACP, FACE, is Professor of Medicine and Adjunct Professor of Pathology at the University of Utah School of Medicine. He is also the Medical Director of the Endocrinology and Automated Endocrinology Laboratory at Associated Regional and University Pathologists (ARUP). Dr Meikle is a Fellow of the American College of Physicians and the American College of Clinical Endocrinology, as well as a diplomate of the American Board of Internal Medicine. He is the Associate Editor of the Reproductive Endocrinology section of the Year Book of Endocrinology and Editor of Endocrine Replacement Therapy in Clinical Practice. Dr Meikle is board-certified in internal medicine, endocrinology, and metabolism and received his MD from Vanderbilt University School of Medicine.

\section{Diagnostic Evaluation}

Measurement of 08:00h serum total testosterone levels ${ }^{29}$ is an initial test used to diagnose hypogonadism. The measurement of total testosterone can be altered in conditions that affect the levels of sex-hormone-binding globulin (SHBG): obesity, nephrotic syndrome, glucocorticoids, aging,

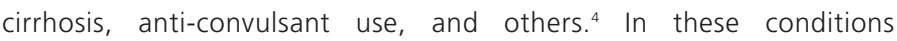
measurement of free or bioavailable testosterone may be helpful. Testosterone levels are affected by illness, and a diagnosis should not be made during acute illness. ${ }^{3}$ FSH and LH levels help to distinguish between primary and secondary hypogonadism. Further work to elucidate the causes of primary and secondary hypogonadism should be pursued (karyotype, prolactin levels, iron profile, other pituitary hormones, and magnetic resonance imaging (MRI) of the pituitary if indicated).

\section{Goals of Treatment}

Testosterone replacement should be given in doses sufficient to approach normal physiological serum concentrations of testosterone and its active metabolites and to avoid adverse effects on the prostate, serum lipids, cardiovascular system, liver, and lung function. ${ }^{5}$

\section{Indications for Treatment}

- Low serum testosterone concentration, plus signs and symptoms of hypogonadism.

- Low bone mineral density with hypogonadism.

- Indications may also include increasing lean body mass and decreasing fat mass and improving energy and mood.

\section{Evidence of Beneficial Effects of Testosterone Replacement Therapy}

- Improved libido and erectile function: Testosterone replacement has been shown to improve libido, frequency of sexual activity, and erectile dysfunction. ${ }^{6}$

- Improved mood: It has also been associated with improved mood, energy, and verbal fluency. ${ }^{7,8}$

- Changes in body composition: Testosterone replacement therapy has been associated with increased lean body mass, decreased body fat, ${ }^{9}$ increase in muscle mass, ${ }^{10}$ increased fat free mass, and decreased fat mass. ${ }^{11-20}$

- Increase in muscle strength: Bhasin et al. ${ }^{26}$ found that T supplementation for 16 weeks in 61 hypogonadal, HIV-infected men aged 18-50 years resulted in increases in muscle volume and strength, whether accompanied by resistance training or not. However, a recent study suggested that replacing testosterone, dehydroepiandrosterone (DHEA), 
Table 1: Hypergonadotropic Hypogonadism

\begin{tabular}{l} 
CONGENITAL \\
\hline Klinefelter's syndrome \\
\hline 47, XYY syndrome \\
\hline Dysgenetic testes \\
\hline Androgen receptor defects \\
\hline 5-alpha reductase deficiency \\
\hline Androgen synthesis defects \\
ACQUIRED \\
\hline Myotonic dystrophy \\
\hline Crypto-orchidism \\
\hline Vanishing testes syndrome \\
\hline Hemochromatosis \\
\hline Trauma \\
\hline Mumps orchitis \\
\hline Radiation \\
\hline Chemotherapy \\
\hline Autoimmune \\
\hline Sertoli cell syndrome \\
\hline HIV \\
\hline Cirrhosis \\
\hline Chronic renal failure \\
\hline Idiopathic \\
\hline Aging \\
\hline Diabetes \\
\hline Metabolic syndrome \\
\hline Opiates \\
\hline
\end{tabular}

or dehydroepiandrosterone sulfate (DHEA-S) in men with baseline mid to high normal levels has little benefit on physical performance and potentially increases risk of side effects. ${ }^{25}$

- Increase in bone mineral density (BMD) but no data on fracture risk: Testosterone replacement has been associated with improvement of trabecular and cortical bone density of the spine in younger and older hypogonadal men. ${ }^{29}$

- Cardiovascular effects: A recent meta-analysis concluded that there is weak evidence to suggest that testosterone use in men with baseline low testosterone levels is not associated with important cardiovascular effects. ${ }^{28}$

\section{Testosterone Replacement}

Daily output of testosterone is about 4-7mg, with the concentrations being higher in the morning and lower in the evening ${ }^{22}$ (see Table 4). There are a variety of formulations on the market, listed below.

\section{Oral Preparations}

The first orally active, synthesized derivative of T was 17- $\alpha$-methyl-T. Blood levels peak at 1.5-2 hours and serum half-life is about 150 minutes, indicating the need for several daily doses to maintain therapeutic levels. Side effects include cholestasis, peliosis, elevation of liver enzymes, and reduction of high-density lipoprotein-cholesterol. ${ }^{5}$ Fluoxymesterone is a 17alpha-methyl testosterone steroid with fluorine in the 9-position and is longer acting than its parent steroid, but is limited by hepatotoxicity. ${ }^{5}$ Mesterolone is derived from 5 -alpha-dihydrotestosterone with a methyl group in the 1-position. It is not hepatotoxic, but relatively large doses must be taken several times a day and dosing is difficult to monitor.
Table 2: Hypogonadotropic Hypogonadism

\begin{tabular}{l} 
CONGENITAL \\
$\begin{array}{l}\text { Idiopathic hypogonadotropic hypogonadism (IHH), } \\
\text { including Kallmann's syndrome }\end{array}$ \\
\hline Genetic defects of gonadotropin sub-units \\
\hline Prader-Willi syndrome \\
\hline Laurence-Moon-Biedl syndrome \\
ACQUIRED \\
\hline Structural \\
\hline Tumors: craniopharyngioma, pituitary adenomas \\
\hline Infiltrative disorders such as sarcoidosis, hemochromatosis \\
\hline Head trauma \\
\hline Radiation \\
\hline Pituitary apoplexy \\
\hline Primary hypothyroidism \\
\hline Functional \\
\hline Exercise \\
\hline Dieting/undernourishment/malnourishment \\
\hline Anabolic steroids \\
\hline Glucocorticoids \\
\hline Narcotics \\
\hline Critical illness \\
\hline Diabetes \\
\hline Nephrotic syndrome \\
\hline Obesity \\
\hline
\end{tabular}

Testosterone undecanoate is an esterified form of testosterone, which is absorbed by lymphatics, by-passing the portal system. Serum testosterone levels tend to vary within the same individual. An advantage is oral administration, but it is not yet available in the US.

\section{Intramuscular Preparations}

Two widely used formulations of testosterone esters are testosterone cypionate and enanthate. Testosterone esters lengthen the retention and duration of activity of the drug. Commonly used regimens are administration of $200 \mathrm{mg}$ of testosterone enanthate or cypionate once every two weeks intramuscular (IM) or $100 \mathrm{mg}$ weekly. Serum testosterone concentrations are supranormal initially and decline to the lower range of normal by the end of two weeks. The advantages of this formulation are that they are inexpensive (if self-administered) and allow flexibility of dosing. The disadvantages are that it is an IM injection and symptoms of energy and libido may vary depending on the serum levels of testosterone. A testosterone undecanoate injection, when given in doses of $1000 \mathrm{mg} I \mathrm{M}$, maintains normal testosterone levels in the majority of patients. ${ }^{3}$ It requires infrequent administration but a large volume $(4 \mathrm{ml})$ in each injection.

\section{Transdermal Preparations}

\section{Trans-scrotal Testosterone}

Scrotal patches deliver approximately $4-6 \mathrm{mg}$ of testosterone daily. ${ }^{30}$ Normal androgen concentrations were achieved in $80 \%$ of hypogonadal men. ${ }^{5}$ Dihydrotestosterone (DHT) levels are elevated and scrotal shaving is necessary for optimal adherence of the patch. 
Table 3: Clinical Characteristics

Decreased lean body mass

Increased fat mass

Decreased muscle mass and strength

Decreased bone mineral density

Decreased libido and erections

Decreased energy

Decreased cognitive function

Decreased sleep quality

Decreased spontaneous erections

Loss of axillary/pubic hair

Decreased frequency of shaving

Hot flushes, sweats

Infertility

Table 4: Formulations for Testosterone Replacement

\begin{tabular}{llll}
\hline Preparation & Dose & Advantages & Disadvantages \\
\hline ORAL & & & \\
\hline 17- $\alpha$-methyl T & 10-40mg/day & Oral administration & $\begin{array}{l}\text { Hepatotoxic, } \\
\text { low HDL }\end{array}$ \\
\hline Fluoxymesterone & $5-20 \mathrm{mg} /$ day & Long-acting & Hepatotoxic \\
& & Oral administration & \\
\hline Mesterolone & $\begin{array}{l}\text { 25-150mg/day } \\
\text { in divided doses }\end{array}$ & Oral administration & $\begin{array}{l}\text { Large doses needed, } \\
\text { dosing difficult to monitor }\end{array}$ \\
\hline T undecanoate & $\begin{array}{l}\text { 120-160mg/day } \\
\text { in divided doses }\end{array}$ & Oral administration & $\begin{array}{l}\text { Varying testosterone levels, } \\
\text { not available in the US }\end{array}$ \\
\hline
\end{tabular}

INTRAMUSCULAR

\begin{tabular}{llll}
\hline $\begin{array}{l}\text { T cypionate or } \\
\text { enanthate }\end{array}$ & $\begin{array}{l}\text { 100mg weekly or } \\
\text { 200mg every two } \\
\text { weeks }\end{array}$ & $\begin{array}{l}\text { Inexpensive } \\
\text { Flexibility of dosing }\end{array}$ & $\begin{array}{l}\text { IM injection } \\
\text { Fluctuating symptoms }\end{array}$ \\
\hline T undecanoate & $\begin{array}{l}\text { Two loading } \\
\text { injections of 1mg }\end{array}$ & $\begin{array}{l}\text { Prolonged action } \\
\text { Potential as a male }\end{array}$ & $\begin{array}{l}\text { Deep and slow intragluteal } \\
\text { injection of large volume }\end{array}$ \\
& $\begin{array}{lll}\text { apart. After this, } \\
\text { 1gm every 12 weeks }\end{array}$ & contraceptive & (4ml) \\
& & & \\
& & &
\end{tabular}

TRANSDERMAL

\begin{tabular}{|c|c|c|c|}
\hline Androderm ${ }^{\circledR}$ & $\begin{array}{l}5 \mathrm{mg} \text { per day starting } \\
\text { dose }\end{array}$ & $\begin{array}{l}\text { Ease of application } \\
\text { Less rise of } \mathrm{Hb}\end{array}$ & Contact dermatitis \\
\hline Scrotal patch & $\begin{array}{l}\text { One patch delivers } \\
4-6 \mathrm{mg} \text { of } \mathrm{T}\end{array}$ & $\begin{array}{l}\text { Physiological } \\
\text { concentration of T }\end{array}$ & $\begin{array}{l}\text { DHT supraphysiological } \\
\text { Scrotal shaving is required }\end{array}$ \\
\hline Androgel ${ }^{\circledR} /$ Testim $^{\circledR}$ & $\begin{array}{l}5 \mathrm{gm} \text { gel } \\
\text { (containing } 50 \mathrm{mg} \\
\text { of } \mathrm{T} \text { ) }\end{array}$ & $\begin{array}{l}\text { Ease of application } \\
\text { Physiologic } \\
\text { concentration of T } \\
\text { No skin irritation }\end{array}$ & $\begin{array}{l}\text { Potential for partner } \\
\text { transfer }\end{array}$ \\
\hline
\end{tabular}

BUCCAL

\begin{tabular}{lll}
\hline Striant ${ }^{\circledR}$ & 30mg CR BID & Physiological concentration of T \\
\hline
\end{tabular}

\section{Non-scrotal Testosterone}

The available formulation is Androderm ${ }^{\circledR}$. One to two patches a day deliver approximately 5-10mg of testosterone and restore physiological ranges of testosterone, DHT, and estradiol. Advantages are ease of application and lesser rise of hemoglobin than injectable esters. Chronic contact dermatitis (mainly from the alcohol component) occurs in about $10 \%$ of hypogonadal men after several weeks of use of Androderm ${ }^{\circledR}$. Two drops of $0.1 \%$ triamcinolone acetonide cream applied to the skin under the central drug reservoir reduces contact dermatitis and itching without significantly affecting testosterone delivery or adrenal function. ${ }^{5}$

\section{Testosterone Gel}

Available formulations are Androge ${ }^{\circledR}$ and Testim ${ }^{\circledR}$. Packets weighing 5, 7.5, or $10 \mathrm{gm}$ contain $50 \mathrm{mg}, 75 \mathrm{mg}$, or $100 \mathrm{mg}$ of testosterone (with systemic absorption of $5 \mathrm{mg}, 7.5 \mathrm{mg}$, or $10 \mathrm{mg}$, respectively). On average, about $10 \%$ of the applied dose is absorbed across the skin, producing physiological ranges of testosterone in blood. Steady-state levels are achieved by the second or third day of dosing. Estradiol concentrations are maintained in the physiological range, but the DHT levels are higher than normal range. ${ }^{3}$ The advantages are ease of administration and good skin tolerability. However, there is potential for transfer of testosterone to partner by direct skin-skin contact. This can be avoided by using a barrier, such as a shirt, to cover the application site. ${ }^{5}$

\section{Buccal Preparation}

The available formulation is Striant ${ }^{\circledR}$, which provides $30 \mathrm{mg}$ controlled-release used twice daily. It is applied to the depression in the gum above the upper incisors and releases testosterone into the peripheral circulation. T and DHT are normalized. Gum-related adverse effects occur in $16.3 \%$ of treated men. ${ }^{32}$

\section{Induction of Fertility by using Human}

Chorionic Gonadotropin

In men with hypogonadotropic hypogonadism desiring fertility, human chorionic gonadotropin ( $\mathrm{hCG}$ ) alone or in combination with human menopausal gonatotropins ( $\mathrm{hMG}$ ) can be used to induce spermatogenesis and fertility. ${ }^{23}$ Since $h M G$ is expensive, hCG is the initial therapy. $\mathrm{hCG}$ can be given IM 1,000-2,000 units two to three times per week. Testosterone levels and sperm counts can be monitored to reach normal levels. Sperm counts lower than normal can be sufficient to induce fertility in such circumstances. If spermatogenesis/induction of fertility have not occurred after 6-12 months, hMG can be added to the regimen at doses of 75 international units (IU) IM three times a week. ${ }^{23}$ This can be increased to 150 IU three times a week in six months, if desired results have not occurred.

\section{Side Effects}

- Erythrocytosis: This has been associated with testosterone replacement therapy, but transdermal preparations tend to have fewer cases of polycythemia compared with testosterone enanthate injections. Erythrocytosis is correlated with elevated bioavailable testosterone and estradiol levels. ${ }^{22}$

- Acne and oily skin.

- Growth of undiagnosed prostate cancer.

- Azoospermia: When used as a means of male contraception, exogenous testosterone induces azoospermia within 10 weeks of therapy. Fertility after cessation of therapy has also been reported. ${ }^{17,18}$

- Changes in lipid profile: A recent meta-analysis showed that there were insignificant changes in low-density lipoprotein and thyroglobulin $(\mathrm{Tg})$ levels after replacement of testosterone in men with low to low-normal testosterone. ${ }^{28}$

- Gynecomastia. 
Figure 1a: Diagnosing Hypogonadism

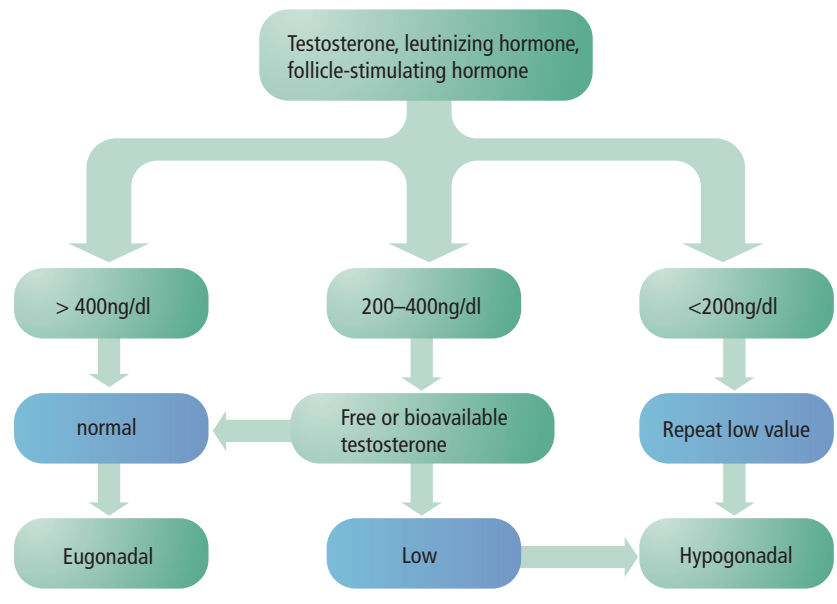

Figure 1b: Diagnosing Primary, Secondary, or Tertiary Hypogonadism

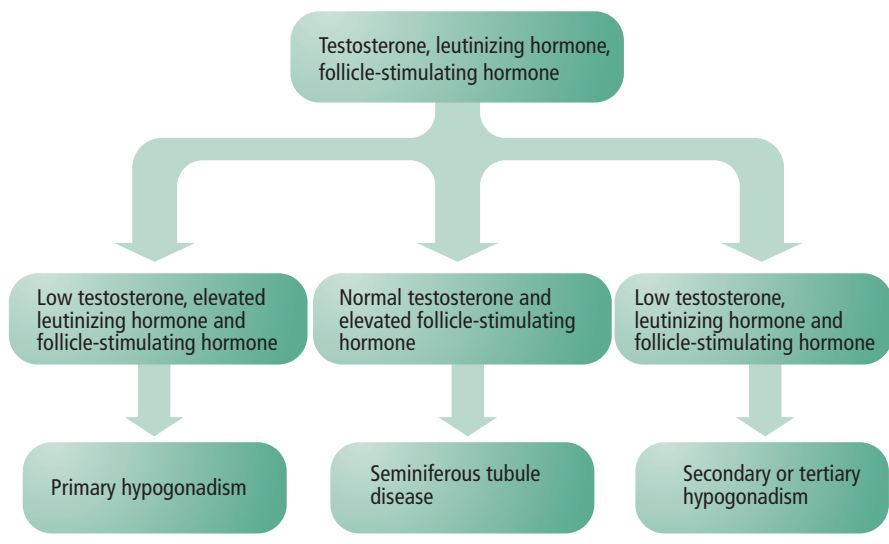

- Worsening of benign prostatic hyperplasia or hypertrophy (BPH) symptoms: A recent study of men with $\mathrm{BPH}$ treated with dutasteride ( $5 \alpha$-reductase inhibitor) suggested that BPH can occur in men considered to be hypogonadal as high levels of 5-reductase and dihydrotestosterone in the prostate allow the development and progression of prostatic hyperplasia, even at low circulating testosterone levels. ${ }^{27}$
- Growth of breast cancer

- New onset or worsening of obstructive sleep apnea.

- Hepatotoxicity (oral preparations).

- Fluctuation of hypogonadal symptoms (IM preparations).

- Dermatitis (transdermal preparations).

- Potential partner testosterone transfer (gels).

- Gum irritation (buccal preparation).

\section{Contraindications}

- Prostate cancer

- Breast cancer

- Undiagnosed prostate nodule.

- Unexplained prostate-specific antigen (PSA) elevation.

- Erythrocytosis.

- Unstable severe congestive heart failure (class III or IV).

\section{Monitoring}

- Periodic symptomatic evaluation: Three months after beginning treatment and then annually.

- Serum testosterone levels: These can be taken 3-12hrs after applications of patch, at least a week after being on testosterone gel, and midway between injectable preparations. The goal is to maintain testosterone in the mid-normal range.

- Hemotocrit (HCT) should be checked at baseline, three months, and then annually. A patient with an HCT $>55 \%$ should be evaluated for hypoxia, sleep apnea, or reduction of testosterone dosage.

- Bone mineral density measurement by dual X-ray absorptiometry should be considered one-to-two years after initiating treatment in patients with low bone mineral density.

- Digital rectal exams (DREs) and PSA level at baseline, three months, and then annually; an abnormal DRE, PSA level $>4 \mathrm{ng} / \mathrm{ml}$, or increase of $>1.4 \mathrm{ng} / \mathrm{ml}$ warrants urological evaluation.

- Evaluated side effects related to different preparations, as detailed in the side effects section.

- Lipid profile: There are no specific recommendations for monitoring the lipid profile, but it may be considered annually, as there are some reports of significant reduction of high-density lipoprotein associated with physiological replacement of testosterone. ${ }^{20}$
1. Santen RJ. In: Yen SSC, Jaffe RB, Barbieri RL (eds), Yen and Jaffe's Reproductive Endocrinology, 4th edn, WM Saunders, 1999;632-75.

2. Reed Larsen $P$, et al. (eds), Williams Textbook of Endocrinology, 10th edn, WB Saunders, 2003

3. Bhasin $\mathrm{S}$, Cunningham GR, Hayes FJ, et al., J Clin Endocrinol Metab, 2006;91:1995-2010.

4. Matsumoto, AM, Rev Urol, 2003;5(Suppl. 1):S3-10

5. Meikle AW, Humana Press, 2003;333-68.

6. Shabsigh R, World J Urol, 1997;15(1):21-6.

7. Meikle AW, Arver S, Dobs AS, et al., In: Bhasin S (ed), Pharmacology, Biology, and Clinical Applications of Androgens, Wiley Liss, Inc., 1996:449-57.

8. Alexander GM, Swerdloff RS, Wang C, et al., Horm Behav, 1998:33(2):85-94

9. Tenover JS, J Clin Endocrinol Metab, 1992;75(4):1092-8.

10. Bhasin S, Storer TW, Berman N, et al., J Clin Endocrinol Metab, 1997:82(2):407-13.

11. Wang C, Swedloff RS, Iranmanesh A, et al., J Clin Endocrinol Metab, 2000;85:2839-53.
12. Brodsky IG, Balagopal P, Nair KS, I Clin Endocrinol Metab, 1996;81:3469-75.

13. Dobs AS, Meikle AW, Arver $S$, et al., J Clin Endocrinol Metab, 1999;84:3469-78.

14. Katznelson L, Finkelstein JS, Schoenfeld DA, et al., J Clin Endocrinol Metab, 1996;81:4358-65.

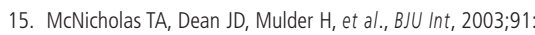
69-74.

16. Snyder PJ, Peachey H, Berlin JA, et al., J Clin Endocrinol Metab, 2000;85:2670-77.

17. Steidle C, Schwartz S, Jacoby K, et al., J Clin Endocrinol Metab, 2003:88:2673-81.

18. Wang C, Cunningham G, Dobs A, et al., I Clin Endocrinol Metab, 2004:89:2085-98.

19. Wang C, Iranmanesh A, Berman N, et al., J Clin Endocrinol Metab, 1998;83:2749-57.

20. Anderson FH, Francis RM, Faulkner, K, et al., Bone, 1996;18: $171-7$.

21. Bremner WJ, Vitiello MV, Prinz PN, J Clin Endocrinol Metab,
1983:56(6):1278-81

22. Arver S, Meikle AW, Dobs AS, et al., Program and Abstracts of the 77th Annual Meeting of the Endocrine Society, Washington DC, June 14-17, 1995;Abstract 1-327.

23. Miyagawa $Y$, Tsujimura A, Matsumiya K, et al., J Urol, 2005;173(6):2072-5

24. AACE Hypogonadism Guidelines, Endocr Pract, 2002;8(No. 6).

25. O'Donnell $A B$, et al., J Clin Endocrinol Metab, 2006;91(2):425-31. Epub 2005 Dec 6.

26. Bhasin S, Storer T, Javanbakht M, et al., JAMA, 2000:293:763-70.

27. Marberger M, et al., J Clin Endocrinol Metab, 2006;91(4):1323-8. Epub 2006 Jan 24

28. Haddad RM, et al., Mayo Clin Proc, 2007;82(1):29-39.

29. Leifke E, Korner HC, Link TM, et al., Eur J Endocrinol, 1998;138:51-8

30. Place VA, et al. In: Nieschlag E, Behre HM, (eds), Testosterone: action, deficiency, substitution, Springer Verlag; 1990:165-80

31. Bhasin S, Buckwalter JG, J Androl, 2001;22:718-731.

32. Wang C, et al., J Clin Endocrinol Metab, 2004;89(8):3821-9. 